\title{
THE MOLYBDATE-STABILIZED GLUCOCORTICOID BINDING COMPLEX OF L-CELLS CONTAINS A 98-100 KDALTON STEROID BINDING PHOSPHOPROTEIN AND A 90 KDALTON NONSTEROID-BINDING PHOSPHOPROTEIN THAT IS PART OF THE MURINE HEAT-SHOCK COMPLEX
}

\author{
Edwin R. Sanchez, Paul R. Housley* and William B. Pratt $\dagger$ \\ Department of Pharmacology, The University of Michigan Medical School, Ann Arbor, MI 48109 ,
} U.S.A.

\begin{abstract}
Summary-This paper summarizes our work performed with glucocorticoid-binding complexes in molybdate-stabilized cytosol prepared from ${ }^{32} \mathrm{P}$-labeled L-cells. In our early work, we showed that cytosol prepared from ${ }^{32} \mathrm{P}$-labeled $\mathrm{L}$-cells contains two phosphoproteins (a 90 and a $98-100$ kdalton protein) that elute from an affinity resin of deoxycorticosterone agarose in a manner consistent with the predicted behavior of the glucocorticoid receptor. Both phosphoproteins are immunoadsorbed onto protein-ASepharose from molybdate-stabilized cytosol incubated with a monoclonal antibody against the receptor. The 98-100 kdalton phosphoprotein binds steroid and the 90 kdalton phosphoprotein is a structurally different, nonsteroid-binding protein that is bound to the untransformed, molybdate-stabilized glucocorticoid receptor. The 90 kdalton protein reacts on Western blots with a monoclonal antibody raised against a 90 kdalton protein from the water mold Achlya ambisexualis. This antibody recognizes an epitope that is conserved in 90 kdalton phosphoproteins from rodent and human cells, and it reacts with the 90 kdalton phosphoprotein that copurifies with the molybdate-stabilized, untransformed chick oviduct progesterone receptor. The 90 kdalton nonsteroid-binding phosphoprotein is an abundant cytosolic protein that dissociates from the glucocorticoid receptor when it is transformed, and unlike the steroid-binding protein, it does not bind to DNA. The 90 kdalton phosphoprotein determines the acidic behavior of the untransformed glucocorticoid reccptor on DEAE-ccllulose. This abundant cytosolic 90 kdalton phosphoprotein reacts with rabbit antiserum raised against the gel purified 89 kdalton chicken heat-shock protein (hsp89). This antiserum recognizes 90 kdalton heat-shock proteins in human, rodent, frog and Drosophila cells. Immunoadsorption of molybdate-stabilized cytosol with antibody directed against the 98-100 kdalton steroid receptor results in the immune-specific adsorption of a 90 kdalton phosphoprotein that reacts with anti-hsp 89 antibody on Western blots. These observations suggest that. like the transforming proteins from several avian sarcoma viruses, the untransformed glucocorticoid receptor exists in a complex with the 90 kdalton heat-shock protein.
\end{abstract}

\section{INTRODUCTION}

The concept that the glucocorticoid receptor is a phosphoprotein derives from early studies of glucocorticoid binding in intact rat thymic lymphocytes [1-3] and mouse L-cells [4]. It was observed that energy is required to maintain the glucocorticoid receptor in a steroid-binding form and that the requirement for energy is independent of new protein synthesis [3-5]. This in turn led to the concept that receptor processing may play an important role in the cycle of events that determine the location and functional state of the receptor in the cell. The model of the glucocorticoid receptor cycle has been discussed in several reviews [6-8].

\footnotetext{
*Present address: Department of Pharmacology, University of South Carolina School of Medicine, Columbia, SC 29208, U.S.A.

†To whom all correspondence should be addressed.
}

Glucocorticoid receptors undergo two types of covalent modification that appear to be important determinants of their function. Reduction of sulfur moieties is clearly required both for the glucocorticoid receptor to bind steroid [9] and for the transformed steroid-receptor complex to bind to DNA [10]. There is evidence that the receptor is maintained in its reduced, steroid-binding state by an NADPH-dependent, thioredoxin-mediated proteinreducing system $[11,12]$. Considerable indirect evidence suggests that phosphorylation is somehow important for maintaining the steroid-binding state of the receptor [13-17], but there is as yet no direct evidence for a role of receptor phosphate in determining a steroid-binding configuration. Nevertheless. it is now quite clear from direct studies that the glucocorticoid binding protein is phosphorylated.

In this paper, we will review our work on the isolation of the molybdate-stabilized glucocorticoid receptor from cytosol of L-cells cultured in the 
presence of $\left[{ }^{32}\right.$ P]orthophosphate. We will show that the molybdate-stabilized receptor complex contains a 98-100 kdalton steroid-binding phosphoprotein and a $90 \mathrm{kdalton}$ nonsteroid-binding phosphoprotein that is structurally distinct from the receptor. This $90 \mathrm{kdalton}$ phosphoprotein is an abundant phosphoprotein species in cytosol with immunoreactive regions that are shared with a similar phosphoprotein that is associated with the molybdate-stabilized avian oviduct progesterone receptor. There is strong evidence to suggest that this $90 \mathrm{kdalton}$, receptorassociated protein is the $90 \mathrm{kdalton}$ murine heatshock protein.

\section{PURIFICATION OF PHOSPHOPROTEINS BY AFFINITY CHROMATOGRAPHY}

Molybdate and some other transition metal oxyanions both stabilize the glucocorticoid receptor in its steroid-binding form and prevent transformation of the steroid-bound receptor to the DNA-binding state $[14,18,19]$. As we want to preserve the receptor in its steroid-binding form during purification, we have added $10 \mathrm{mM}$ sodium molybdate to all buffers in our experiments with "2P-labeled receptor [20, 21]. The site-specific affinity label [H]dexamethasone 21-mesylate [22] was used to identify the glucocorticoid receptor on gel electrophoresis under denaturing conditions [20]. A typical profile from our early experiments is shown in Fig. 1. The major specifically labeled species migrated at 90,000 and a minor species migrated at 98,000-100,000. Accord- ingly, we focued our attention on identifying ${ }^{32} \mathrm{P}$-labeled proteins of this size.

In the experiments shown in Fig. 2, L-cells in monolayer culture were grown in in the presence of $\left[{ }^{32} \mathrm{P}\right]$ orthophosphate for $18 \mathrm{~h}$ prior to harvest. The glucocorticoid binding proteins in molybdatestabilized cytosol prepared from these cells were purified by affinity chromatography on a column of deoxycorticosterone-agarose and submitted to sodium dodecyl sulfate-polyacrylamide gel electrophoresis (SDS-PAGE). In lane 1 the affinity column was eluted with $11 \alpha$-cortisol, a cortisol isomer with no glucocorticoid activity, and in lane 2 the active isomer $11 \beta$-cortisol was present. The presence of the active glucocorticoid produced increased elution of a major phosphorylated species migrating at 90,000 and a slightly larger species with a molecular mass of 98-100kdalton. These two phosphoproteins migrated on SDS PAGE in the same manner as the species shown in Fig. 1 which bind $\left[{ }^{3}\right.$ H]dexamethasone mesylate in a specific manner. To test whether the proteins were bound to the affinity column in a manner characteristic of the high-affinity steroidbinding property of the receptor, ${ }^{32} \mathrm{P}$-labeled cytosol was preincubated with $50 \mathrm{nM}$ triamcinolone acetonide in order to occupy the receptor sites prior to exposure to the affinity matrix. As shown in lane 3. there is much less of the $90 \mathrm{kdalton}$ species and none of the $100 \mathrm{kdalton}$ species in this sample.

From these observations we concluded that both phosphoproteins possess a high-affinity stereospecific binding site for glucocorticoids. The strongest evi-

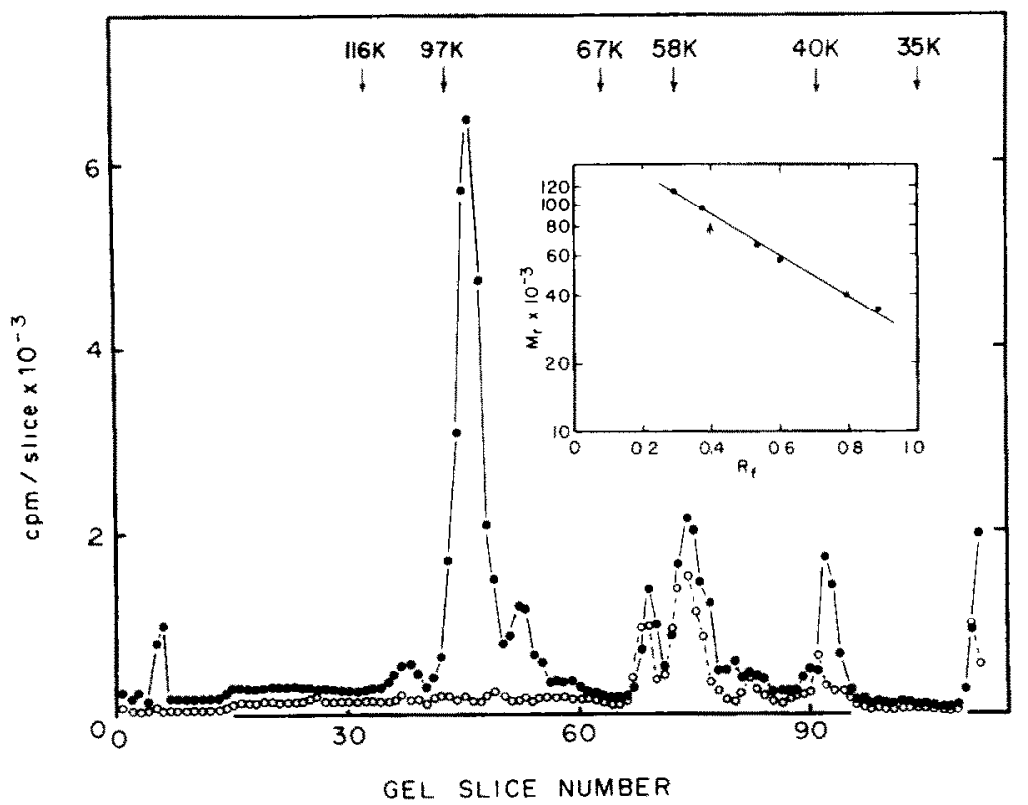

Fig. 1. SDS -PAGE of [ $\left.{ }^{3} \mathrm{H}\right]$ dexamethasone mesylate-labeled L-cell cytosol. Cytosol was incubated at $0-4 \mathrm{C}$ with $50 \mathrm{nM}\left[{ }^{3} \mathrm{H}\right]$ dexamethasone mesylate and either vehicle $(O)$ or $50 \mu \mathrm{M}$ unlabeled dexamethasone $(O)$. and submitted to SDS-PAGE. Samples lanes were cut into $1 \mathrm{~mm}$ slices, digested, and radioactivity was determined by liquid scintillation counting. The inset illustrates the standard curve used to obtain the molecular weight of the covalently-labeled receptor by using proteins of known molecular weight. From Housely and Pratt[20]. 

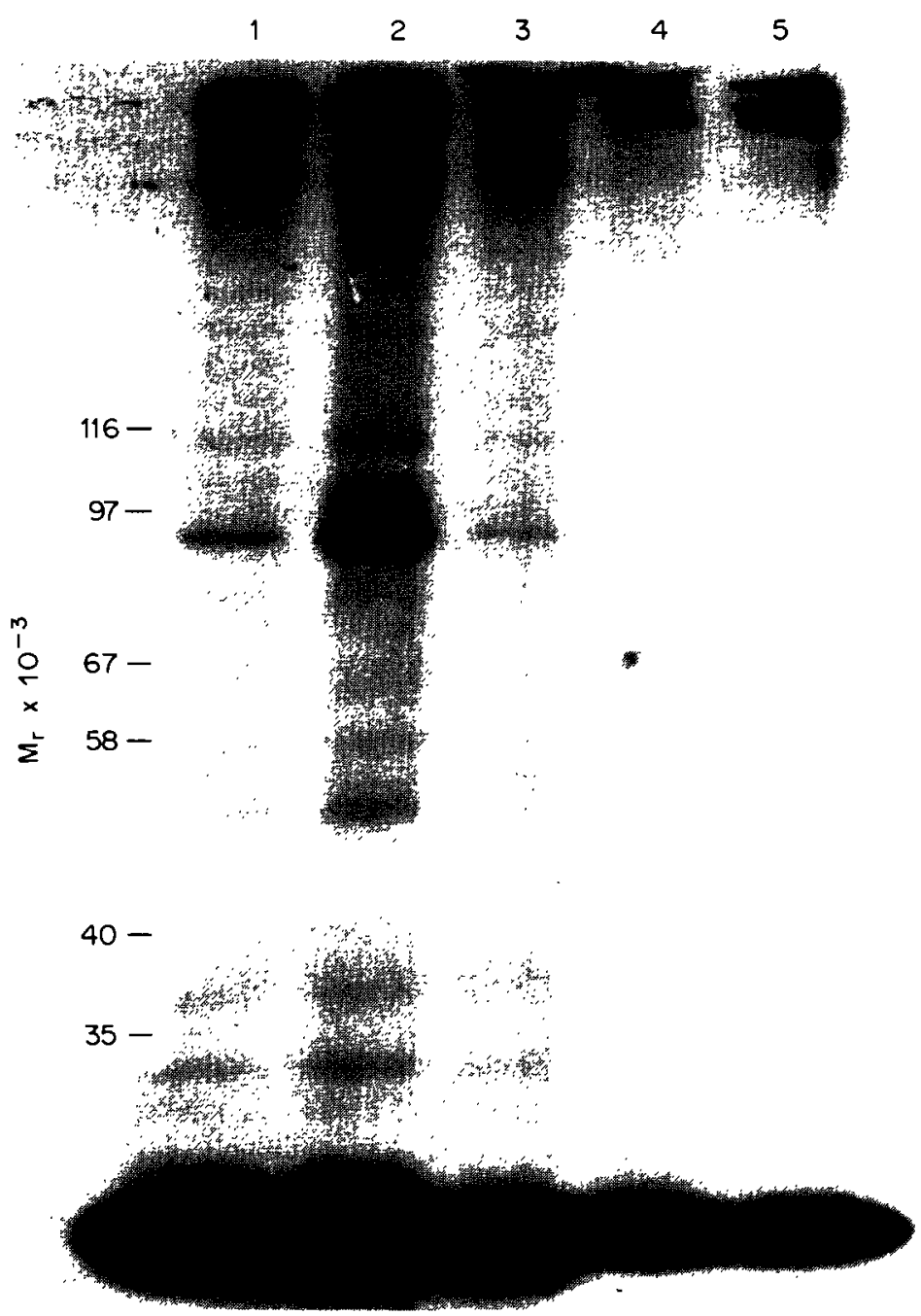

Fig. 2. Stereospecific elution of ${ }^{32}$ P-labeled cytosol proteins from deoxycorticosterone-agarose. Molybdate-stabilized cytosol prepared from ${ }^{32} \mathrm{P}$-labeled L-cells was incubated with the affinity agarose to bind receptor and the column was eluted with the indicated isomer of cortisol. Following SDS-PAGE, the $\left[{ }^{32} \mathrm{P}\right]$ phosphoproteins were visualized by autoradiography. Lane 1 , elution with the physiologically inactive compound $11 \alpha$-cortisol: lane 2 , elution with the active glucocorticoid $11 \beta$-cortisol; lane 3 , cytosol preincubated with $50 \mathrm{nM}$ triamcinolone acetonide and then incubated with the affinity column and eluted with $11 \beta$-cortisol: lane $4,11 \alpha$-cortisol elution of ${ }^{32} \mathrm{P}$-labeled cytosol from glucocorticoid-resistant L-cells: lane 5, $11 \beta$-cortisol elution of ${ }^{32} \mathrm{P}$-labeled cytosol from resistant L-cells. From Housley and Pratt[20].

dence that the 90 and 100 kdalton phosphoproteins are related to the glucocorticoid receptor is shown in lanes 4 and 5 of Fig. 2. In this case, a cloned glucocorticoid-resistant subline of L929 cells with only $5 \%$ of the binding capacity of the parent cells was incubated with $\left[{ }^{32} \mathrm{P}\right]$ or thophosphate and the cytosol proteins were submitted to affinity chromatography. The affinity column eluates from resistant cells contain much less 90 kdalton phosphoprotein and none of the $98-100$ kdalton phosphoprotein.

At the time this work was performed, we did not know if the $98-100$ kdalton protein labeled with dexamethasone mesylate was the unaltered receptor and the 90 kdalton species was a cleavage product or if the two steroid-binding proteins were products of different genes. However, we made the assumption that both of the ${ }^{32} \mathrm{P}$-labeled proteins contained steroid-binding sites and thus that both proteins represented receptor. While we were proceding with experiments designed to further purify these phosphoproteins, we noted that we were recovering more ${ }^{32} \mathrm{P}$-radioactivity in the $98-100$ kdalton region of the affinity column eluate than we had in our orignal studies. This increase in the intensity of the 98-100 kdalton band was accompanied by some decrease in the intensity of the ${ }^{32} \mathrm{P}$-labeling in the 90 kdalton band. We therefore eluted the affinity column with $\left[{ }^{3} \mathrm{H}\right]$ dexamethasone mesylate and found that the only species labeled by the affinity ligand in a specific manner migrated above the $97 \mathrm{kdalton}$ phosphorylase marker at $98-100$ kdalton [21]. This 
suggested to us that the 90 kdalton species we had previously observed by labeling with $\left[{ }^{3} \mathrm{H}\right]$ dexamethasone mesylate was a cleavage product of the 98-100 kdalton species. Our affinity column eluates from ${ }^{32} \mathrm{P}$-labeled L-cell cytosol still contained both 90 and $98-100$ kdalton phosphoproteins. These observations suggested that we might have one steroid-binding protein but two phosphoproteins in the affinity column eluate. It was clear that we would have to purify receptor by a method that did not employ affinity chromatography in order to resolve this problem. Accordingly, we formed a collaboration with Hannes Westphal and Miguel Beato who had developed a monoclonal antibody (GR49) against the purified rat glucocorticoid receptor that cross-reacts with the mouse receptor [23].

\section{PURIFICATION OF PHOSPHOPROTEINS BY IMMUNOADSORPTION WITH ANTIRECEPTOR ANTIBODY}

To begin the second phase of our work, we again examined the binding of the site-specific affinity ligand in L-cell cytosol [21]. [ $\left.{ }^{3} \mathrm{H}\right]$ Dexamethasone mesylate-bound receptors in molybdate-stabilized cytosol were incubated with the monoclonal antibody, adsorbed to protein-A-Sepharose, and resolved by SDS-PAGE. In contrast to our original observations. on this occasion we found that the only protein labeled in a specific manner migrated on SDS-PAGE at 98-100 kdalton (cf. Fig. I with Fig. 4, lane 2). The only $\left[{ }^{3} \mathrm{H}\right]$ dexamethasone mesylate-bound protein brought down by the monoclonal antibody also migrated above the phosphorylase marker at 98-100 kdalton [21]. However, the antibody clearly caused the immune specific adsorption of an additional protein migrating at 90,000 that was readily visualized by Coomassie blue stain but did not bind the affinity ligand. As shown in Fig. 3, when cytosol from ${ }^{32} \mathrm{P}$-labeled L-cells is reacted with the monoclonal antibody, we recover a ${ }^{32} \mathrm{P}$-labeled band at $98-100$ kdalton that is not seen with nonimmune mouse $\mathrm{IgG}$ and there is a marked increase in ${ }^{32} \mathrm{P}$-labeling in the $90 \mathrm{kdalton}$ region compared to that seen in the nonimmune control lane.
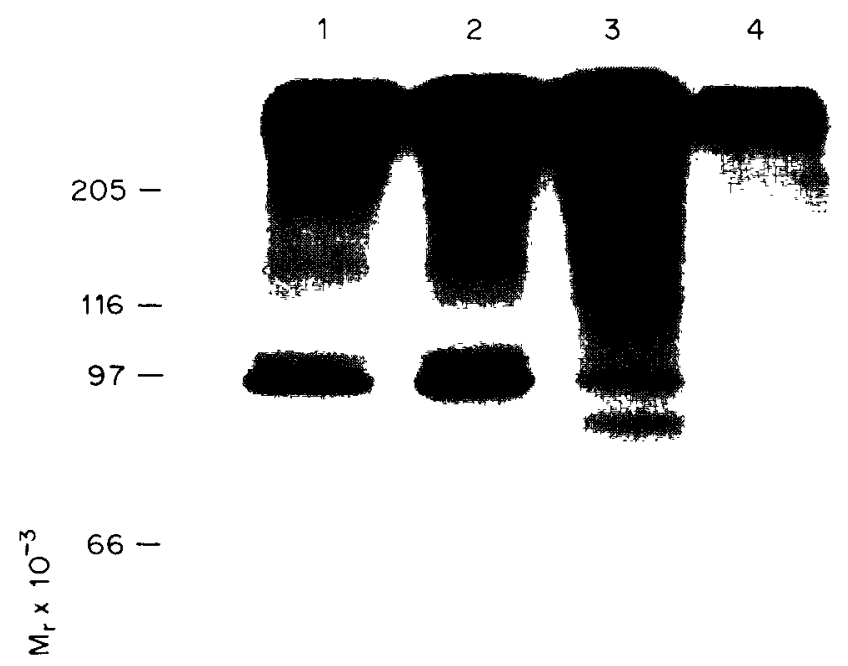

$45-$

Fig. 3. Extraction of ${ }^{32} \mathrm{P}$-labeled protein from L-cell cytosol with monoclonal antibody and protein-ASepharose. Four $400 \mu \mathrm{l}$ aliquots of ${ }^{32} \mathrm{P}$-labeled L-cell cytosol were mixed with an equal volume of buffer and bound with $50 \mathrm{~nm}$ nonradioactive dexamethasone. Each aliquot was incubated for $12 \mathrm{~h}$ on ice with monoclonal antibody, or with nonimmune mouse $\operatorname{lgG}$ (each at $5 \%$ of volume), or with no immunoglobulin. At the end of the incubation, each sample was bound to protein-A-Sepharose for $2 \mathrm{~h}$. The protein-A-Sepharose-bound material was washed and samples were resolved by electrophoresis on a $9 \%$ SDS-PAGE and autoradiography. Lane 1, ammonium sulfate purified GR49 monoclonal antibody; lane 2 , the same antibody purified on protein-A-Sepharose; lane 3 , nonimmune mouse IgG; lane 4 , no immunoglobulin addition. From Housley et al.[21]. 
1

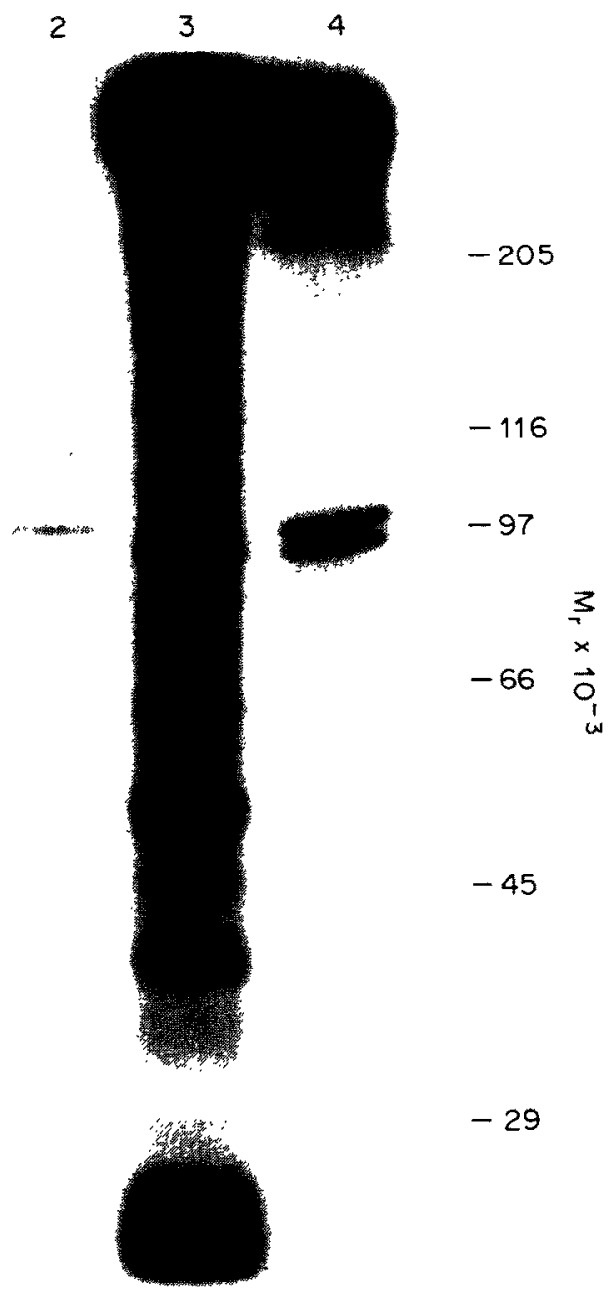

Fig. 4. Comparison of $\left[{ }^{3} \mathrm{H}\right]$ dexamethasone mesylate-labeled receptor with ${ }^{32}$-labeled L-cell cytosol proteins after reaction with monoclonal antibody. L-cell cytosol was incubated with $50 \mathrm{nM}$ $\left[{ }^{3} \mathrm{H}\right]$ dexamethasone mesylate in the presence or absence of 1000 -fold excess of nonradioactive dexamethasone, and $300 \mu \mathrm{l}$ of each incubation was further incubated with monoclonal antibody and protein-A-Sepharose. Aliquots $(100 \mu \mathrm{l})$ of ${ }^{32} \mathrm{P}$-labeled L-cell cytosol were incubated with monoclonal antibody and protein-A-Sepharose in the same manner. Samples applied to each lane of a $7 \%$ SDS-PAGE were: lane $1,300 \mu \mathrm{l}$ of cytosol incubated with [ $\left.{ }^{3} \mathrm{H}\right] \mathrm{dexamethasone}$ mesylate in the presence of excess nonradioactive dexamethasone; lane $2,300 \mu \mathrm{l}$ of cytosol incubated with [ $\left.{ }^{3} \mathrm{H}\right]$ dexamethasone mesylate alone: lane 3, $100 \mu \mathrm{I}$ of ${ }^{32} \mathrm{P}$-labeled cytosol; lane $4,100 \mu \mathrm{l}$ of ${ }^{32} \mathrm{P}$-labeled L-cell cytosol mixed with $300 \mu 1$ of $\left[{ }^{3} \mathrm{H}\right]$ dexamethasone mesylate-labeled cytosol before addition of monoclonal antibody. The gel was visualized by autoradiography using EN ${ }^{3}$ HANCE. From Housley et al. [21].

The experiment in Fig. 4 was performed to show that the $98-100 \mathrm{kdalton}$ protein labeled with $\left[{ }^{3} H\right]$ dexamethasone mesylate and the $90 \mathrm{kdalton}$ ${ }^{32}$ P-labeled protein can clearly be resolved from each other. L-cell cytosol labeled with [ $\left.{ }^{3} \mathrm{H}\right]$ dexamethasone mesylate, or ${ }^{32} \mathrm{P}$-labeled cytosol, or a mixture of the two preparations was incubated with the monoclonal antibody and protein-A-Sepharose. Although it is difficult to achieve the optimal proportions of each labeled cytosol to react with antibody and put on the gel lane, there is a line of continuity between the [ ${ }^{3}$ H]dexamethasone mesylate-labeled band in lane 2, a ${ }^{32} \mathrm{P}$-labeled band in lane 3 and the upper band in the doublet recovered from the mixture in lane 4 . Again, by this method the dexamethasone mesylate-labeled protein is distinct from the $90 \mathrm{kdalton}$ phos. phoprotein.

The 90 kdalton phosphoprotein is an abundant protein in L-cell cytosol and some of it adsorbs to protein-A-Sepharose when nonimmune IgG or even when no IgG is present (Fig. 3, lanes 4 and 5). If nonradioactive L-cell cytosol is added to protein-ASepharose prior to addition of ${ }^{32} \mathrm{P}$-labeled cytosol containing the immune complexes, this background radioactivity at $90 \mathrm{kdalton}$ can be eliminated and both the 90 and $98-100 \mathrm{kdalton}{ }^{32} \mathrm{P}$-labeled bands are adsorbed in a manner that is completely immunespecific. In immunoblot experiments it was shown 
that the monoclonal antibody reacts only with the $98-100 \mathrm{kdalton}$ protein. Thus, the $90 \mathrm{kdalton}$ nonsteroid-binding phosphoprotein is present in the immunoadsorbed material because it is associated with the receptor.

As the 90 kdalton, nonsteroid-binding phosphoprotein copurifies with the receptor by two independent methods, one of which is based on recognizing a steroid-binding site and the other on recognizing an antibody binding site, we would propose that the $90 \mathrm{kdalton}$ phosphoprotein is a component of the molybdate-stabilized, untransformed glucocorticoid-receptor complex in L-cell cytosol [21]. As the 90 kdalton phosphoprotein is eluted in abundance from the deoxycorticosterone agarose affinity matrix in a manner that is consistent with the presence of a glucocorticoid-binding site and as the $98-100$ kdalton steroid-binding protein is cleaved to varying degrees in cytosol preparations, it is easy to see how we and others have made the assumption that the 90 kdalton phosphoprotein is the receptor. The error is particularly easy to make in rat liver cylosol preparations where the receptor exists as a 94 kdalton protein. The [ $\left.{ }^{3} \mathrm{H}\right]$ dexamethasone mesylate-labeled receptor in rat liver cytosol migrates at the top edge of the Coomassie blue stain for the 90 kdalton protein. There are now several studies involving ${ }^{32} \mathrm{P}$-labeling of rat liver proteins in vivo or in vitro followed by purification by affinity chromatography under molybdate-stabilized conditions where the abundantly phosphorylated $90 \mathrm{kdalton}$ band has been assumed to be the receptor.

\section{STUDIES WITH A MONOCLONAL ANTIBODY} AGAINST 90 kdalton PHOSPHOPROTEIN

The observations we have reported here are identical to those reported by Mendel et al.[24] for the molybdate-stabilized glucocorticoid-receptor complcx of mouse thymoma cells, and they are very similar to those reported from the laboratories of Toft[25-27] and Baulieu[28-30] for the molybdatestabilized avian progesterone receptor complex. Sullivan et al.[27] and Joab et al.[30] have prepared monoclonal antibodies against the $90 \mathrm{kdalton}$ nonsteroid-binding phosphoprotein that is associated with the chick oviduct progesterone receptor in the untransformed $8 \mathrm{~S}$ complex. In each case it has been demonstrated by sedimentation analysis on sucrose gradients that one of the anti- 90 kdalton antibodies interacts with molybdate-stabilized glucocorticoid and androgen receptors in chick oviduct cytosol. These observations support a general model in which untransformed steroid receptors are associated with one or more $90 \mathrm{kdalton}$ nonsteroid-binding phosphoproteins. The stoichiometry of the two phosphoproteins in the untransformed complex is not known and it is possible that other nonsteroidbinding proteins that have not yet been identified are also components of the untransformed receptor complex.
It seems rather clear that if we are going to understand the process of glucocorticoid receptor transformation, we are going to have to know more about the interaction of the $90 \mathrm{kdalton}$ protein with the receptor. Toft and his coworkers have developed a monoclonal antibody to a 90 kdalton phosphoprotein purified from Achlya ambisexualis, a water mold that has steroid receptors which are stabilized in an $8 \mathrm{~S}$ complex by molybdate [31]. This AC6 monoclonal antibody reacts with the $90 \mathrm{kdalton}$ phosphoprotein that is associated with the chick oviduct progesterone receptor, and its reactive site is directed against an epitope that is conserved in $90 \mathrm{kdalton}$ proteins in a variety of avian, rodent and human cells. Accordingly, we formed a collaboration with Dave Toft and have used the AC6 antibody to study the $90 \mathrm{kdalton}$ phosphoprotein of $\mathrm{L}$-cells. When ${ }^{32} \mathrm{P}$-labeled $\mathrm{L}$-cell cytosol is incubated with the AC6 monoclonal antibody, a 90 kdalton phosphoprotein is adsorbed to protein-A-Sepharose and it comigrates on SDS PAGE with the 90 kdalton phosphoprotein brought down from molybdate-stabilized L-cell cytosol with the GR49 monoclonal antibody against the receptor. The $90 \mathrm{kdalton}$ phosphoprotein is present in cytosol in very large amounts, as judged by Coomassie blue stain and by fluorography of ${ }^{32}$ P-labeled gels.

The AC6 antibody does not cause the immunoadsorption of the untransformed $\left[{ }^{3} \mathrm{H}\right]$ triamcinolone acetonide-receptor complex to protein-A-Sepharose. It can be demonstrated by the immunoblot technique, however, that the antibody reacts with the $90 \mathrm{kdalton}$ protein that is immunoadsorbed when molybdatestabilized cytosol is reacted with the GR49 monoclonal antireceptor antibody or with rabbit antiserum raised aginst the mouse glucocorticoid receptor. In the experiment shown in Fig. 5, L-cell cytosol containing molybdate-stabilized untransformed receptor was incubated with prcimmune rabbit scrum (lane 1), antiserum against the glucocorticoid receptor (lane 2) or the AC6 antibody against the 90 kdalton protein (lane 3). Each sample was adsorbed to protein-ASepharose, resolved by SDS-PAGE, and transferred onto nitrocellulose paper. The nitrocellulose blot was incubated first with the AC6 monoclonal antibody and the $90 \mathrm{kdalton}$ protein was visualized by the horeseradish peroxidase method. Like the GR49 monoclonal antibody, the rabbit antiserum against the receptor caused the $90 \mathrm{kdalton}$ protein to be immunoadsorbed to protein-A-Sepharose. It is clear from lane 1 that the preimmune serum does not cause the adsorption of any $90 \mathrm{kdalton}$ protein. After the immunoblot was reacted with the AC6 antibody and developed with peroxidase, it was reacted with the GR49 monoclonal antibody against the receptor and developed again. This caused the development of the major bands at $98-100 \mathrm{kdalton}$ as well as three cleaved forms of the receptor seen as one band just above and two bands below the $90 \mathrm{kdalton}$ nonsteroid-binding protein. Again, from examining 


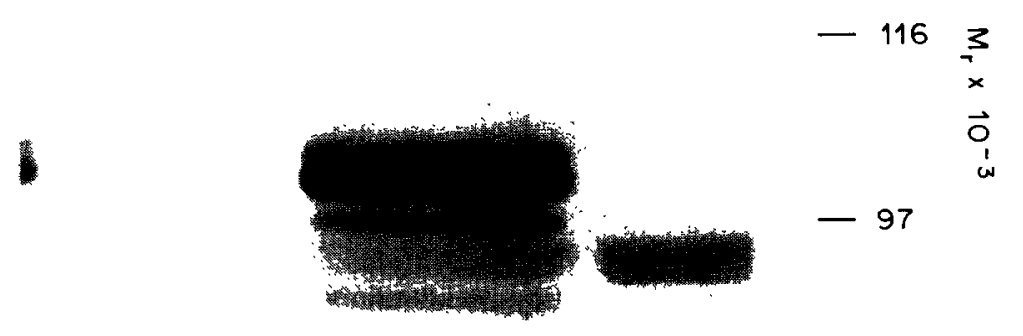

Fig. 5. Immunoblot of L-cell cytosol proteins immunoadsorbed to protein-A-Sepharose with either rahbit antireceptor antiserum or with the AC6 monoclonal antibody. Aliquots of L-cell cytosol were mixed with equal volumes of TEG buffer containing $10 \mathrm{mM}$ sodium molybdate and $10 \mathrm{mM}$ DTT and incubated for $2 \mathrm{~h}$ at $4^{\circ} \mathrm{C}$ with either the AC6 monoclonal antibody or rabbit sera at the concentrations indicated below. The immune complexes were bound to protein-A-Sepharose and the pellets were washed with TEG buffer containing molybdate and DTT. Samples were electrophoresed in a 7\% SDS-PAGE and transferred onto nitrocellulose paper. The nitrocellulose paper was washed in blocking buffer $(20 \mathrm{mM}$ Tris, $50 \mathrm{mM} \mathrm{NaCl}$, $1 \%$ bovine serum albumin and $0.5 \%$ Tween-20, $\mathrm{pH} 7.6$ ) and incubated with the AC6 monoclonal antibody at a final concentration of $40 \mu \mathrm{g} / \mathrm{ml}$ for $11 \mathrm{~h}$ at $4^{\circ} \mathrm{C}$. The AC6 monoclonal antibody is specific for the 90 kdalton nonsteroid-binding phosphoprotein. The nitrocellulose was then washed with blocking buffer and incubated for $1 \mathrm{~h}$ at $20^{\circ} \mathrm{C}$ with a $1 / 250$ dilution of HRP-conjugated goat anti-mouse IgG. The nitrocellulose was then washed in Tris buffered saline ( $\mathrm{pH}$ 7.6) followed by color development, utilizing 4-chloro-1-napthol as substrate, according to the method of Hawkes et al.[32]. This process was then repeated on the same nitrocellulose strip. but this time using a 1/4 dilution of GR49 hybridoma fluid as the probe antibody. This fluid contains monoclonal antibody specific to the 98 kdalton steroid-binding phosphoprotein [21]. The nitrocellulose was washed, incubated with HRP-conjugated goat anti-mouse IgG and the color was developed. Lane 1, $200 \mu \mathrm{l}$ of $\mathrm{L}$-cell cytosol incubated with $10 \%$ rabbit preimmune serum; lane 2, $200 \mu \mathrm{l}$ of L-cell cytosol incubated with $10 \%$ rabbit antiserum against the mouse L-cell glucocorticoid receptor; lane 3, $100 \mu \mathrm{l}$ of L-cell cytosol incubated with $2 \%$ AC6 monoclonal antibody.

an immunoblot experiment such as this, one can readily appreciate how the glucocorticoid receptor and the nonsteroid-binding phosphoprotein have been confused with each other in recent reports from a variety of laboratories.

The association of the $90 \mathrm{kdalton}$ protein with the glucocorticoid receptor is of high affinity, but if molybdate is not present in the buffers used to wash the protein-A-Sepharose pellets containing the immunoadsorbed untransformed receptor complex, then the 90 kdalton protein is dissociated. If receptors in $\mathbf{I}$-cell cytosol are transformed by heating prior to addition of molybdate, incubation with antireceptor serum and adsorption to protein-A-Sepharose, then very little of the 90 kdalton phosphoprotein is recovered. This loss of the 90 kdalton protein during heating of cytosol is prevented by the presence of molybdate. Several laboratories have observed that transformation of glucocorticoid-receptor complexes is accompanied by a reduction in their size from an apparent mol. wt of $\sim 320,000$ to $\sim 100,000$, leading to the proposal that transformation involves dissociation of the receptor either from itself or from nonsteroid-binding components [33-35]. Transformation to the DNA-binding state and the reduc- tion in molecular size are prevented by molybdate. It has been known for some time that the untransformed glucocorticoid-receptor complex elutes from DEAE columns at higher salt than the transformed complex [36] and that molybdate preserves all of the receptor in this more acidic form [37]. When L-cell cytosol containing untransformed receptors and molybdate is adsorbed to DEAE-cellulose and eluted with $\mathrm{KCl}$, the $98-100$ kdalton steroid-binding phosphoprotein and the 90 kdalton phosphoprotein are both eluted at $0.21-0.25 \mathrm{M} \mathrm{KCl}$. If cytosol containing temperature-transformed receptors is submitted to DEAE-cellulose chromatography, then the steroid-binding protein is eluted at lower salt (about $0.1 \mathrm{M} \mathrm{KCl}$ ) but the elution of the 90 kdalton phosphoprotein is unchanged. Thus, it would seem that the acidic behavior of the untransformed receptor is determined by the charge properties of the 90 kdalton nonsteroid-binding protein with which it is associated. Taken together, our observations are consistent with the proposal that the $90 \mathrm{kdalton}$ nonsteroidbinding protein dissociates from the receptor during the transformation process. The L-cell receptor then binds to DNA as a $98-100$ kdalton moiety that is released by pyridoxal 5'-phosphate and can be 
immunoadsorbed and visualized by the Western procedure. The $90 \mathrm{kdalton}$ phosphoprotein does not bind to DNA.

\section{THE 90 kdalton PHOSPHOPROTEIN IS A MURINE HEAT-SHOCK PROTEIN}

Several laboratories have reported that $90 \mathrm{kdalton}$ proteins isolated by affinity chromatography from chick oviduct or rat liver cytosol are phosphorylated on incubation with $\left[\gamma^{32} \mathrm{P}\right] \mathrm{ATP}$ and either $\mathrm{Mg}^{2+}$ or $\mathrm{Ca}^{2+}[38-40]$. This has led to the speculation that the 90 kdalion protein may be a protein kinase that undergoes autophosphorylation $[38,40]$. Recently. we have examined phosphorylation of the 90 kdalton and the $98 \mathrm{kdalton}$ proteins of L-cell cytosol after purification by immunoadsorption onto protein-ASepharose. In our system, we are able to demonstrate phosphorylation of the $98 \mathrm{kdalton}$ protein by an endogenous L-cell protein kinase but we cannot demonstrate intrinsic protein kinase activity on the part of either the $90 \mathrm{kdalton}$ or the $98 \mathrm{kdalton}$ protein in the immune complex [41].

Although it has not yet proven possible to ascribe an enzymatic function to the 90 kdalton protein associated with the L-cell glucocorticoid receptor, it is possible to demonstrate a relationship between this protein and $90 \mathrm{kdalton}$ proteins studied in other systems. As the AC6 antibody recognizes an epitope that is shared by both chicken and murine 90 kdalton phosphoproteins that copurify with molybdatestabilized progesterone and glucocorticoid receptors these two receptor-associated proteins are related. As the AC6 antibody was developed against a 90 kdalton protein derived from a water mold and interacts with 90 kdalton phosphoproteins of avian, rodent and human origin, it is clear that elements of the protein have been highly conserved during evolution. Thus, we know several facts about the 90 kdalton receptorassociated protein: (1) it has regions that are highly conserved with primitive eukaryotes; $(2)$ it is present in a wide variely of cell types; (3) it is phosphorylated on serine residues; and (4) it exists in abundance in cytosol. Taken together these observations lead one to think of the $90 \mathrm{kdalton}$ murine heat-shock protein (hsp90) as a likely candidate for the receptorassociated protein.

Hsp90 is one of the mammalian heat-shock proteins. It is a cytosolic phosphoprotein (on serine) that exists in abundance in mammalian cells [42]. Mammalian hsp90 is related to chicken hsp89 and Drosophila hsp83, which has been studied in considerable detail [42]. In 1982, Kelley and Schlesinger prepared a polyclonal antibody against gel-purified chicken hsp 89 and demonstrated that it reacts with proteins of similar mobilities in human, rodent, frog and Drosophila cells [43]. Accordingly, we formed a collaboration with Milton Schlesinger and asked if the rabbit antibody against the chicken hsp 89 would interact with the $90 \mathrm{kdalton}$ protein isolated from molybdate-stabilized L-cell cytosol using antibodies against the receptor. First, we demonstrated that the 90-kdalton L-cell protein immunoadsorbed onto protein-A-Sepharose with the AC6 monoclonal antibody reacts with the anti-hsp89 antibody [44]. We then showed that immunoadsorption of molybdatestabilized cytosol by the polyclonal rabbit antiserum of the GR49 monoclonal antibody against the receptor results in the immune-specific presence of a $90 \mathrm{kdalton}$ protein that interacts with the anti-hsp 89 antibody on Western blot [44].

In summary, using antibodies against each component, we have shown that the untransformed glucocorticoid receptor in molybdate-stabilized L-cell cytosol exists in a complex with the 90 kdalton murine heat-shock protein. When the receptor is transformed, it dissociates from hsp90 and binds to DNA as a $98-100 \mathrm{kdalton}$ species. The proteins mediating transformation of cells infected with Rous (pp60 ${ }^{\mathrm{rc}}$ ), Fujinami (pp140 $0^{\mathrm{fps}}$ ) and Y73 (pp94 ${ }^{\text {yes }}$ ) avian sarcoma viruses [45-47] also associate with hsp90. It is interesting to note that when cells infected with Rous sarcoma virus containing a temperature-sensitive defect in the src gene are grown at the nonpermissive temperature, more than $90 \%$ of the pp $60^{\text {src }}$ molecules are associated with hsp90, whereas at the permissive temperature, the complex dissociates, although not as rapidly as in cells infected with wild type virus. It will be interesting to see if molybdate has the effect of stablizing complexes between hsp90 and viral transforming proteins in the same manner that it stabilizes hsp90-steroid receptor complexes.

Acknowledgements - These investigations werc supported by Grant CA28010 from the National Cancer Institute. Funds supporting travel to this meeting for E. Sanchez and W. B. Pratt were provided by Pharmacology Associates of Ann Arbor, Mich.

\section{REFERENCES}

1. Munck A. and Brinck-Johnsen T.: Specific and nonspecific physiocochemical interactions of glucocorticoids and related steroids with rat thymus cells in titro. J. biol. Chem. 243 (1968) 5556-5565.

2. Munck A., Wira C., Young D. A., Mosher K. M., Hallahan C. and Bell P. A.: Glucocorticoid- receptor complexes and the earliest steps in the action of glucocorticoids on thymus cells.. J. steroid Biochem. 3 (1972) 567-578.

3. Bell P. A. and Munck A.: Steroid binding properties and stabilization of cytoplasmic glucocorticoid receptors from rat thymus cells. Biochem. J. 136 (1973) 97-107.

4. Ishii D. N., Pratt W. B. and Aronow L.: In vitro degradation and stabilization of the glucocorticoid binding component from mouse fibroblasts. Biochemistry 11 (1972) 3896-3904.

5. Sloman J. C. and Bell P. A.: The dependence of specific nuclear binding of glucocorticoid by rat thymus cells on cellular ATP. Biochim. biophys. Acta 428 (1976) 403-413.

6. Munck A. and Leung K.: Glucocorticoid receptors and mechanisms of action. In Receptors and Mechanism of Action of Steroid Hormones (Edited by J. R. Pasqualini). Dekker, New York (1977) pp. 311-397. 
7. Housley P. R., Grippo J. F., Dahmer M. K. and Pratt W. B.: Inactivation, activation and stabilization of glucocorticoid receptors. In Biochemical Actions of Hormones, Vol. XI (Edited by G. Litwack). Academic Press, New York (1984) pp. 374-376.

8. Munck A. and Holbrook N. J.: Glucocorticoidreceptor complexes in rat thymus cells. Rapid kinetic behavior and a cyclic model. J. biol. Chem. 259 (1984) 820.831 .

9. Rees A. M. and Bell P. A.: The involvement of receptor sulfhydryl groups in the binding of steroids to the cytoplasmic glucocorticoid receptor from rat thymus. Biochim. biophys. Acta 411 (1975) 121-132.

10. Bodwell J. E., Holbrook N. J. and Munck A.: Sulfhydryl modifying reagents reversibly inhibit binding of glucocorticoid-receptor complexes to DNA-cellulose. Biochemistry 23 (1984) 1392-1398.

11. Grippo J. F., Tienrungroj W., Dahmer M. K., Housley P. R. and Pratt, W. B.: Evidence that the endogenous heat-stable glucocorticoid receptor-activating factor is thioredoxin. J. biol. Chem. 258 (1983) 13658-13664.

12. Grippo J. F.. Holmgren A. and Pratt W. B.: Proof that the endogenous, heat-stable glucocorticoid receptoractivating factor is thioredoxin. J. biol. Chem. 260 (1985) 93-97.

13. Nielsen C. J., Sando J. J. and Pratt W. B.: Evidence that dephosphorylation inactivates glucocorticoid receptors. Proc. natn. Acad. Sci. U.S.A. 74 (1977) 1398-1402.

14. Nielsen C. J., Sando J. J., Vogel W. M. and Pratt W. B.: Glucocorticoid receptor inactivation under cellfree conditions. J. biol. Chem. 252 (1977) 7568-7578.

15. Sando J. J., LaForest A. C. and Pratt W. B.: ATPdependent activation of $\mathrm{L}$ cell glucocorticoid receptors to the steroid-binding form. J. biol. Chem. 254 (1979) $4772-4778$

16. Sando J. J., Hammond N. D., Stratford C. A. and Pratt W. B.: Activation of thymocyte glucocorticoid receptors to the steroid-binding form. The roles of reducing agents, ATP. and heat-stable factors. J. biol. Chem. 254 (1979) $4779-4789$

17. Housley P. R., Dahmer M. K. and Pratt W. B.: Inactivation of glucocorticoid binding capacity by protein phosphatases in the presence of molybdate and complete reactivation by dithiothreitol. $J$, biol. Chem. 257 (1982) 8615-8618.

18. Leach K. L., Dahmer M. K., Hammond N. D., Sando J. J. and Pratt W. B.: Molybdate inhibition of glucocorticoid receptor inactivation and transformation. $J$. biol. Chem. 254 (1979) 11884-11890.

19. Dahmer M. K., Housley P. R. and Pratt W. B.: Effects of molybdate and endogenous inhibitors on steroid receptor inactivation, transformation and translocation. A. Rev. Physiol. 46 (1984) 67-81.

20. Housley P. R. and Pratt W. B.: Direct demonstration of glucocorticoid receptor phosphorylation by intact Lcells. J. biol. Chem. 258 (1983) 4630-4635.

21. Housley P. R., Sanchez E. R., Westphal H. M., Beato M. and Pratt W. B.: The molybdate-stabilized L-cell glucocorticoid receptor isolated by affinity chromatography or with a monoclonal antibody is associated with a $90-92-\mathrm{kDa}$ non-steroid-binding phosphoprotein. J. biol. Chem. 260 (1985) 13810-13817.

22. Simons S. S., Jr, and Thompson E. B.: Dexamethasone 21-mesylate: an affinity label of glucocorticoid receptors from rat hepatoma tissue culture cells. Proc. natn. Acad. Sci. U.S.A. 78 (1981) 3541-3545.

23. Westrhal H. M., Mugele $K$., Beato $M$, and Gehring U.: Immunological characterization of wild-type and variant glucocorticoid receptors by monoclonal antibodies. EMBO Jl 3 (1984) 1493-1498.

24. Mendel D. B., Bodwell J. E., Gametchu B., Harrison R. W. and Munck A.: Nonactivated glucocorticoid receptors contain a non-steroid-binding phos- phoprotein in addition to the steroid-binding phosphoprotein. Submitted.

25. Dougherty J. J., Puri R. K. and Toft D. O.: Phosphorylation in vivo of chicken oviduct progesterone receptor. J. hiol. Chem. 257 (1982) 14226-14230.

26. Dougherty J. J., Puri R. K. and Toft D. O.: Polypeptide components of two $8 \mathrm{~S}$ forms of chicken oviduct progesterone receptor. J. hiol. Chem. 259 (1984) 8004 8009 .

27. Sullivan W. P., Vroman B. T., Bauer V. J., Puri R. K., Riehl R. M., Pearson G. R. and Toft D. O.: Isolation of a steroid receptor binding protein from the chicken oviduct and production of monoclonal antibodies. Biochemistry. In press.

28. Renoir J.-M. Mester J., Buchou T., Catelli M.-G., Touhimaa P., Binart N.. Joab I., Radanyi C. and Baulieu E.-E.: Purification by affinity chromatography and immunological characterization of a $110-\mathrm{kDa}$ component of the chick oviduct progesterone receptor. Biochem. J. 217 (1984) 685-692.

29. Radanyi C., Joab I., Renoir J.-M., Richard-Foy H. and Baulieu E.-E.: Monoclonal antibody to chicken oviduct progesterone receptor. Proc. natn. Acad. Sci. U.S.A. 80 (1983) $2854-2858$.

30. Joab I., Radanyi C., Renoir M., Buchou T., Catelli M.-G., Binart N., Mester J. and Baulieu E.-E.: Common non-hormone binding component in nontransformed chick oviduct receptors of four steroid hormones. Nature 308 (1984) 850-853.

31. Riehl R. M, and Toft D. O.: Analysis of the steroid receptor of Achlia arntrisexualis. J. biol. Chem. 259 (1984) 4534-4541.

32. Hawkes R., Niday E. and Gordon J.: A dotimmunoblotting assay for monoclonal and other antibodies. Analyt. Biochem. 119 (1982) 142-147.

33. Holbrook N. J., Bodwell J. E., Jeffries M. and Munck A.: Characterization of nonactivated and activated glucocorticoid-receptor complexes from intact rat thymus cells. J. biol. Chem. 258 (1983) 6477-6485.

34. Sherman M. R., Moran M. C. Tuazon F. B. and Stevens Y.-W.: Structure, dissociation, and proteolysis of mammalian steroid receptors. J. biol. Chem. 258 (1983) 10366-10377.

35. Vedeckis W. V.: Subunit dissociation as a possible mechanism of glucocorticoid receptor activation. Biochemistry 22 (1983) 1983-1989.

36. Sakaue Y. and Thompson F. B.: Characterization of two forms of glucocorticoid hormone-receptor complex separated by DEAE-cellulose column chromatography. Biochem. biophys. Res. Commun. 77 (1977) 533-541

37. Dahmer M. K., Quasney M. W., Bissen S. T. and Pratt W. B.: Molybdate permits resolution of untransformed glucocorticoid receptors from the transformed state. $J$. biol. Chem. 256 (1981) 9401-9405.

38. Garcia T., Tuohimaa P., Mester J., Buchou T., Renoir J.-M. and Baulieu E.-E.: Protein kinase activity of purified components of the chicken oviduct progesterone receptor. Biochem. biophys. Res. Commun. 113 (1983) 960-966.

39. Kurl R. N. and Jacob S. T.: Phosphorylation of purified glucocorticoid receptor from rat liver by an endogenous protein kinase. Biochem. biophys. Res. Commun. 119 (1984) 700-705.

40. Miller A. S., Schmidt T. J. and Litwack G.: Protein kinase activity of purified rat hepatic glucocorticoid receptor. Proc. VII Int. Congr. Endocr., Quebec (1984) Abstr. 1056.

41. Sanchez E. R. and Pratt W. B.: Phosphorylation of L-cell glucocorticoid receptors in immune complexes: evidence that the receptor is not a protein kinase. Biochemistry. In press.

42. Craig E.: The heat shock response. Crit. Ret. Biochem. In press. 
43. Kelley P. M. and Schlesinger M. J.: Antibodies to two major chicken heat shock proteins react with similar proteins in widely divergent species. Molec. cell. Biol. 2 (1982) 267-274.

44. Sanchez E. R., Toft D. O., Schlesinger M. J. and Pratt W. B.: The 90-kDa non-steroid-binding phosphoprotein that binds to the untransformed glucocorticoid receptor in molybdate-stabilized L-cell cytosol is the murine $90-\mathrm{kDa}$ heat shock protein. J. biol. Chem. 260 (1985) 12398-12401.

45. Brugge J. S.. Erickson E. and Erickson R. L.: The specific interaction of the Rous sarcoma virus transforming protein, $\mathrm{pp} 60^{\mathrm{scc}}$, with two cellular proteins. Cell 25 (1981) 363-372.

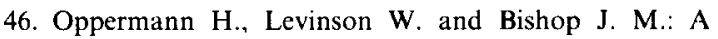
cellular protein that associates with the transforming protein of Rous sarcoma tirus is also a heat-shock protein. Proc. natn. Acad. Sci. U.S.A. 78 (1981) 1067-1071.

47. Lipsich L. A., Cutt J. R. and Brugge J. S.: Association of the transforming proteins of Rous, Fujinami, and Y73 avian sarcoma viruses with the same two cellular proteins. Molec. cell. Biol. 2 (1982) 875-880.

48. Brugge J., Yonemoto W. and Darrow D.: Interaction between the Rous sarcoma virus transforming protein and two cellular phosphoproteins: analysis of the turnover and distribution of this complex. Molec. cell. hiol. 3 (1983) 9-19. 